\title{
MALAY AUTHORSHIP IN \\ LANDSKAP UNGU: \\ FROM ARTISTIC SOURCE TO \\ INTELLECTUAL IMPACT
}

(Kepengarangan Melayu dalam Landskap Ungu:
daripada Sumber Seni kepada Dampak Kebijaksanaan)

Arbak Othman

\begin{abstract}
This article discusses the contribution of Dato' Ahmad Kamal Abdullah or Kemala regarding the development of Malay poetry in Malaysia and the history of Malay poetry in the archipelago. This article is based fully on the essays compiled in Landskap Ungu (2010). It examines Kemala's contribution to the Malay art of poetry composition, the approach or the evaluation used in analyzing Malay poetry, specifically in interpreting Islamic poetry and the country's sociopolitical landscape, as well as comparing the quality of the art of poetry of international poets with that of some of Malaysia's poets. Apart from that, other issues are also discussed, such as the art concept of sufi poetry which is the basic expression of some Malay poets, either in Indonesia or Malaysia. Kemala's contribution is exceptional and has proven to be very significant in the development of Malay poetry with regard to his capability as a critic and a disciplined researcher, especially in the world of Malay poetry. His level of thought and intellectualism boost the quality of the art of expression of creative thinking locally or universally.
\end{abstract}

Keywords: epistemology, aesthetics, hermeneutics, irony, critiques, literature, mystique, thinker, sufi, sufi poetry, semiotic, symbolism, theory of literature

\section{Abstrak}

Makalah ini menghuraikan sumbangan Dato' Ahmad Kamal Abdullah atau Kemala terhadap perkembangan puisi Melayu di Malaysia dan sejarah puisi Melayu di Nusantara. Penulisan makalah ini berlandaskan hasil tulisan beliau sepenuhnya, iaitu esei yang terkumpul dalam karya terbaik beliau, Landskap Ungu (2010) terbitan Penerbit UPM. Makalah ini meneliti 
sumbangan Kemala dalam dunia perpuisian Melayu, seni dan gubahan puisi, pendekatan atau ukuran kualiti yang digunakan dalam penganalisisan puisi Melayu, khususnya untuk mentakrif puisi Islam dan sosiopolitik tanah air, serta perbandingan kualiti seni pengungkapan puisi penyair antarabangsa yang dibandingkan dengan puisi beberapa penyair tanah air. Selain itu, beberapa kecenderungan lain turut dibicarakan seperti konsep seni puisi sufi yang menjadi asas pengucapan beberapa penyair Melayu, baik di Indonesia mahupun di Malaysia. Sumbangan Kemala amat istimewa dan terbukti sangat besar dalam perkembangan perpuisian Melayu kerana keupayaan beliau sebagai pengkritik dan pengkaji yang berdisiplin, terutamanya dalam dunia kepenyairan Melayu yang dikatakan sudah mencapai tahap kematangan yang boleh dibanggakan. Tahap pemikiran dan keintelektualan beliau meningkatkan kualiti seni pengucapan fikiran yang kreatif sama ada bersifat setempat mahupun universal.

Kata kunci: epistemologi, estetik, etika, hermeneutik, kritikan, kesusasteraan, mistik, pemikir, sufi, puisi sufi, semiotik, simbolisme, teori kesusasteraan

\section{INTRODUCTION}

We seldom come across the viewpoints such as those deduced from Kemala's research in Landskap Ungu. Although the issues are assorted and varied, most of the poems observed are focused on Islamic poetry created and published in Malaysia. Among the subjects studied are the aspects of quality of poetic art, aesthetics, inclinations in the art of poetry as well as the philosophy of faith, spirit and light in Islamic poetry. Most poets are more biased towards poetry which exposes and questions the subjects of grief and sorrow of the Malays experienced by the Malay society and culture in Malaysia. Kemala sees that there is an intense need for happiness of body and soul in the Malay society as believers of Islam, a religion synonymous with the "Malay race" in this part of the archipelago.

The collection of essays in Landskap Ungu (2010) by Ahmad Kamal Abdullah not only researched the level of achievement in Malay poetizing based on genre inclination, but also observed the power of genre as expressing the thinking tool of Malays. Poetry can be used as a means to awaken particular groups of people to take heed of the contents expressed in Malay poetry since the poets usually display positive attitudes with the intention of uplifting and improving the situation of the Malay race and the Malay language that is languishing within its own shores. Islamic poetry is among the type of poetry that should be given attention by the new generation since the content 
embedded within it is very effective as a means of relief or cure for diseases of the soul, unsettled or disturbed minds, irrationality and mental block. Kemala uses sources of knowledge, in the form of information or theory for both Islamic and sufi poetry. Sufi poetry requires the mind to interpret the sublimity of God. Sufi poetry can also be the light (guidance) that inspires men to feel and acquire true happiness in this world and the hereafter.

Some of his poetry are used as a basis for comparison. Here we find that Kemala does not defend his own thoughts but explores in the context that is permitted by the methods and ethics of literature through words and meanings based on the semiotic approach. Also, he is honest, has sincere intentions and is non-biased.

Kemala's poetry is regarded as sufi poetry as its contents emphasise the purity of the soul as interpreted in the teachings of tasawuf (path of the sufis) (Aceh, 1989, pp. 27-28). The word sufi is derived from the word shufi from the verb shafa' meaning clean and pure (Hamka, 1984, p. 86), and from sophia, the Greek word meaning wisdom or philosophy (Aceh, 1989, p. 25; Nasution, 1990, p. 57). Since Kemala includes not only aesthetic but also ethical elements, his poetry is considered as sufist poetry. This includes his poems in the collection of 'Ayn (1983), Pelabuhan Putih (1989), Titir Zikir (1995), Mim (1999), and Ziarah Tanah Kudup (2006). These poems are excluded from his other poetry that are also part of his struggle for a superior sociocultural environment that God favours. A study made on the poem "Wujud" in the poetry collection 'Ayn (1983), sees the role of light in darkness. Kemala sees the color green as the sign of the sublimity of Allah. According to him, Allah manifests His might and will on earth through the green color. This symbolism is clearly pictured in the poem "Wujud" (Landskap Ungu 2010, p. 211) as follows:

\begin{tabular}{|l|l|}
\hline Hijau, hijau kebun anggur Lembah & [Green, green is the vineyard of \\
Barossa & Barossa Valley \\
Hijau, hijau kebun sayur Ranau Kinabalu & Green, green is the vegetable garden \\
Hijau, hijau teratai subur kebunraya & of Ranau Kinabalu \\
Bogor & Green, green is the fertile lotus of \\
Kanggaroo berlompatan & Bogor Botanical Garden \\
Merak mengigal-ngigalan & Kangaroos hop about \\
Ikanmas berenang-renangan & Peacocks strut around \\
Kijang-kijang berlari-larian & Goldfish swim around \\
Peri wujud terpancar & Deer running about \\
Terkumpul dari sumbernya & Radiating the nature of existence \\
Keindahan yang Satu! & Manifestation of the Creator \\
& The beauty of the One and Only!] \\
\hline
\end{tabular}


Existence can only mean the characteristic and reality of the One God, that is God exists. This hermeneutic meaning can only be perceived by someone close to God.

Kemala is not a sufi but a sufi poet. His poems describe his mystical experiences and is also one of the means he uses to glorify the sublimity of God. His mystical experiences often have a poetic quality. Poetic or aesthetic experience embraces mystical quality. Through effective poetry, personality, uniqueness and directness are well preserved. A basic mystic concept is "the aspect of godliness as beauty". In Kemala's poetry, sometimes the figurative or personified (majas) meaning of verses from the Qur'an are quoted to address the concept of godliness. This concept of godliness usually requires symbolic language as used in the Quran. In the poetry written by Kemala or others who love figurative meanings, they emphasise the closeness of relationship between men and The Creator. Often, the statements of beauty revolve around the beauty created by The One. Kemala describes the beauty of God's creation through the words he expressed in his poetry. To realize his feelings of awe toward the creation of The Creator, words such as lover, palace, house, garden, field, river, mountain, leaves, cloud, trees, dew, coolness and snow (kekasih, istana, rumah, taman, padang, sungai, gunung, daun, awan, pohon, embun, dingin and salju) are often used.

\section{AS AN INTERPRETER}

As an interpreter, Kemala does direct or open translation on the texts he studies. To him, figurative language as in the form of metaphor and metonymy gives assurance and value expressed by the texts, and develops with age and maturity. He regards the rejection of assurance and cultural values as a mistake since assurance and values must go together.

In other words, almost all of the studies compiled in Landskap Ungu use the appropriate theory on poetic communication so that the meanings contained in the poetry can be interpreted. He understands the symbolic expressions in poetry and strives to extract the real meaning or interpretation of the phrases. This is evident when he analyzes poetry with Islamic elements such as those by several Malay poets like Darma Mohammad, Latiff Mohidin, Wahab Ali, Suhaimi Haji Muhammad, and others. In addition, sometimes he uses the semiotic method overlapping it with the hermeneutic approach, although among the scholars, most of them would prefer a comprehensive or inclusive approach or the hermeneutic theory. This approach is easier to 
understand, i.e. an approach that makes undecipherable expressions simpler, and then interpreted through the process of poetic interpretation.

The writer comes to such a conclusion because the question of truth with regards to "our world" (a social world/life owned by all) is answered through the universal-pragmatic structural application, which is logic based on the aspect of development due to its dynamic feature. In his writing, Kemala tries to make the hermeneutic interpretation on a basis which is less dependent on context, that is essential in the semiotic approach. The leniency is allowed because the interpretive imbalance between the framework of universalpragmatic theory and the concrete expression of life of social culture can be overcome by applying hermeneutics as a reading lens.

Kemala is able to understand the meaning of texts as long as he feels responsible to present the truth by expressing particular meanings, values and norms. As an interpreter, Kemala is able to read the context assumed by the general reader who reads the poetry he researches. He uses his erudition to interpret the text, and presents his argument to strengthen the true meaning of the poetry in order for them to be accepted as logical and believable. The writer believes that Kemala defends the performative attitude he has acquired as a communication speaker, even while studying the preconceptions on which the texts are based. Most of the essays in Landskap Ungu provide insights into the beauty of poetic texts, expressed through the quality of the poetry, art of expression and philosophy of thought. Hence, the way in which Kemala structures his creative product to show manifestation of beauty inherent in the body of Malay poetry.

\section{AS A SERIOUS RESEARCHER}

Kemala's studies on the country's poetry is done through research. In his appreciation of the poetry of Baha Zain, Muhammad Haji Salleh and Latiff Mohidin, he contends that the aesthetic in the beautiful structure of expression of which the artistic poetic quality is unquestionable. These creative productions are food for the soul of the readers. Kemala tries to explore this in his effort to empower and promote the work of other poets who have contributed to Malay poetry development in Malaysia. Poetry, with its economy of words and focus on the spiritual, demonstrate a projection of superior activity which the readers need to be informed. The thinking that goes into the aesthetics and ethics in poetry on various matters hinges on sociocultural reality whereby the basis of reflection and agenda of the poets 
to effect changes based on a preferred platform for the society's attention and observation.

In poetry, the beauty within manifests the meaning; coloring the truth with mental patterns is required in poetry aesthetics. According to Braginsky, meaning is the structure of the poetry's spirit (Abdul Hadi W.M., 2001, p. 77). The spirit in the poetry is studied by Kemala in order to place several poems by contemporary poets at the front line in bringing about changes according to the character of the spirit in the poetry. Kemala uses his power of imagination to demarcate any existing differences according to the capability of the poets in their individual poetry.

His study of Syair Rakis in Lanskap Ungu (1965) which was written for the purpose of saving the beloved country (Brunei Darussalam) from falling into the hands of traders who were the puppets of colonialism exemplifies the importance of a poet's political agenda. He extracted the intellectual thinking through the cognitive value and the mental assumptions from the symbols in the poetry. He scrutinized the poetry to summarize the contents in order to enable the people to understand the meaning of the poetry as a work of literature as a political context. Certainly his research took a long time in order to get the correct interpretation from the language symbols used in the poetry.

In essence, Syair Rakis brings a message for future generations to always be receptive to changes. Only those knowledgeable in classical and modern literature and have the knowledge of Islam are able to interpret the contents of the poetry that are in the nature of teachings, advice, lessons, reminders and deliberations in its original form. Kemala is that person. Words like aksara (font), menyurat (lettering), olah johari (work of the intellect), dagang asmara (love trade), lanjar, chenchudek, ma'abot, bubut, melaila, umbut (plant shoot), setiatin, gangsal (five) tersamu, and others must be understood before interpreting the definition or meaning of the expression in layman's language. The symbolism in Syair Rakis is complex. Only a person of culture and who possesses the historical knowledge of the language and the Brunei Sultanate will be able to interpret the truth. Since the poetry concerns the future politics in Brunei Darussalam, an interpreter is treading on dangerous ground if anything in the interpretation causes unwanted consequences that could bring about the downfall of the nation. Since Kemala is a writer, researcher and poet with insightful acumen in the structure of poems and poetry, his ability to translate ideology, philosophy and thought contained in Syair Rakis is admirable and should be honored, at least in this effort which is socio-politically risky. 


\section{PLACING ONESELF IN THE CREATIVE PROCESS}

It is not surprising that Kemala hopes to find the virtue of spiritualism in the work of Malay poetry. Poetry is the medium of expression from the spiritual journey, in fact it has been a part of the social event often expressed by poets in their effort to produce the power of art in their creative work. Some truths that are expressed by contemporary poets perceived thought as beauty, and this impression becomes the special focus in social phenomena, which by nature contains the superiority of culture in the life of a society. The virtues of love and kindness are used by the country's poets as the basis for their creative works.

\section{As a Researcher of Intellectual Poetry Quality}

The statement "Muhammad found the intellectualism he was seeking" proves that he diligently studied the quality of Malay poetry based on values and the intellect. He provided an example in his attempt to apply the value of intellectualism in Malay poetry. The existence of intellectualism formed from the connotation and interpretive interpretation highlights the changes in modern Malay poetry. In Dharmawijaya's poem entitled Dengan Kasih Sayang, Kemala sees the changes that mark the structure of poetic expression in the poem below:

\begin{tabular}{|l|l|}
\hline Dengan rasa kasih sayang & [With feelings of love and affection \\
Mari kita ke sawah ladang & Let us go to the paddy fields \\
Kenal dan mengertikan & Be acquainted with and understand \\
Pada senyum tangis kehidupan & The laughter and sorrow of life \\
Milik berabad anak-anak kami & The possession of our children for \\
Melemas usia di bawah jerih mentari & $\begin{array}{l}\text { centuries } \\
\text { Drowning age in the weariness of the } \\
\text { sun] }\end{array}$ \\
\hline
\end{tabular}

Although the changes are not evolutional, Kemala considers that the changes began in the 60s, especially in terms of "economic expression and the influence of pantun which was still very strong" in its structure (Landskap Ungu, 2010, p. 129). The intellectual value is more significant in the poetry of Muhammad Haji Salleh whom he considers as a critical poet with his intuition which is said to be "revolutionary". This is perceived by Kemala as a new feature because the changes displayed by Muhammad Haji Salleh showed that he was trying to transform the existing mentality; if possible, he 
proposes that Malay poetry move forward without restraint or having to abide by the traditional form usually applicable to much of the poetry in the 60 s and $70 \mathrm{~s}$ in Malaysia. Kemala appreciates the changes made by Muhammad as a sign that modern Malay poetry was beginning to have Baudelaire's dynamic feature that "dives deep in the ocean bed" and "into unknown territory" to discover something new (Landskap Ungu, 2010, p. 133).

\section{POETS AS THINKERS AND CREATORS OF POETIC ART}

Kemala often dives into the deep seas, climbs the high mountains, without paying attention to whether fame will boost the names of the local poets whom he considers as thinkers and philosophers. He places the importance of poetry in the context of its benefits to society and country. By quoting the views of V. I. Braginsky in Gejala (Kemala, 1989, p. 518-519), he too admires the work of Baha Zain who exposes the truth of opposing values of the real and the fake which is his philosophy in poetry. Baha Zain is known as a poet who understands the role of words and is aware of the traits of humanity. Kemala agrees with the views of Muhammad Haji Salleh and Baha Zain. To quote Baha Zain, "poetry is the extension from the evolving personality, displaying the style, form and color of which the meanings and advantages are hard to understand. Poetry is never pompous for its statements often call for sympathy from an open heart and a proper understanding" (Landskap Ungu, 2010, p. 66). Kemala regards Baha Zain as the poet who blazes the heat of protest in his poems. He categorises Baha Zain as a poet who represents his period thus making Kemala to be among the respectable poets who are grateful to the others who have greatly contributed to the development of Malay poetry. Kemala appreciates the opinions and thoughts of others. These characteristics make him a poet of great empathy because of his concern for the good of the society, culture and nation.

Kemala delves into the worldviews of Baha Zain which encompass the international world (Landskap Ungu, 2010, p. 70) for his sharp criticism of the American policy that created devastation in the Vietnam War during the $60 \mathrm{~s}$, and the downfall of western civilization which made use of the dollar, the napalm and gonorrhea to take over the poor third world and destroy them, Kemala focused his thinking ability in the domain that recognizes the struggle of other poets. He believes in dakwah (preaching), an obligation demanded by the teaching of Islam. Dakwah is an obligatory responsibility of every Muslim toward other Muslims. In his studies he sees the poets as 
embracing their duty as preachers because they use poetry as the platform for their expression of thought and philosophy of human life locally and universally.

Kemala's praise for Baha Zain as a poet whom he considers as someone who fights for a mental revolution involving those who are "weak and submissive", who criticizes the fraudulent and pretentious elites with their pseudo-arts and wealthy indulgence as well as building a strong support and art base" (Landskap Ungu, 2010, p. 72). Like Baha Zain, he possesses the same qualities as an observer and analyst of situations. As a learned researcher, who is far-sighted, fair and just, Kemala has made many refreshing contributions to the Malay-Indonesian world of poetry with the poetic philosophy in poetry.

How can a poet become a thinker? If language scholars can become thinkers just by interpreting language usage in social interactions, poets too interpret language that is more beautiful through literary creativity which is of great benefit to the culture and identity of a race. Poets use beautiful language in poetry; a language that reaches the foundation of common sense to express ideas that inspire goodness, perfection and vitality in the realm of consciousness which is formative and constructive, not destructive. In other words, poets are more dynamic in suggesting better things that can be applied in one's life. Only those who are ignorant regard a work of poetry as the creation of unending sorrow and frustration. They fail to look at themselves as unwilling to change from being selfish, an attitude not permissible by the religion. Only poets are able to wake them up from their sleep after having made a mockery of God's commands and committed what is not beneficial to the society, just for the sake of power and self-pride.

Finally it is the poets who can function as the admonisher of mistakes and imbalances prevalent in a society. To channel the reprimands, the poets require skill to write in a language that people would like to read, or in a language that entertains created in beautiful word arrangements. Through beautiful language the poets present their opinions, issues, proposals and intellectual decisions, usually by the use of gentle words with meanings that calm the soul. This skill requires talent and vast knowledge in order to express spiritual ideas such as the light of faith as food for the soul of those who are close to God. These ideas are expressed effectively in the poetry collections Ayn, Pelabuhan Putih, Titik Zikir, Mim and Ziarah Tanah Kudup as presented in chapter 22 which is entitled "Delving into the Malay and Indonesian Characteristics" in Ayn, Pelabuhan Putih, Titik Zikir, Mim and 
Ziarah Tanah Kudup (Landskap Ungu, 2010, p. 415-450). In Indonesia, poets such as A. Mustofa Bisri and Abdul Hadi W. M. are categorized as fresh sufi thinkers, well-versed in the knowledge of tauhid and noble spirits.

Kemala's gentle soul can be read calmly and clearly in the poetry collection mentioned earlier. The poems in 'Ayn express the self-experience of the poet in the metaphysical world of perfect quality, in a beautiful and musical rhythm, as in the poem Ada (Landskap Ungu, 2010, p. 212) below:

\begin{tabular}{|c|c|}
\hline $\begin{array}{l}\text { Ada jejariku menjadi pohonpohonan } \\
\text { kecil }\end{array}$ & [My fingers become small plants \\
\hline $\begin{array}{l}\text { Ada tanganku menjadi dahandahan } \\
\text { peneguh arah }\end{array}$ & $\begin{array}{l}\text { My arms become branches reinforcing } \\
\text { direction }\end{array}$ \\
\hline $\begin{array}{l}\text { Ada kakiku menjadi jambatan } \\
\text { merentangi }\end{array}$ & $\begin{array}{l}\text { My legs become bridges across the } \\
\text { creek }\end{array}$ \\
\hline $\begin{array}{l}\text { Ada telingaku menjadi rumpun } \\
\text { bambu yang rendang }\end{array}$ & My ears become shady bamboo shrubs \\
\hline $\begin{array}{l}\text { Ada rambutku menjadi serabut akar } \\
\text { kaktus }\end{array}$ & $\begin{array}{l}\text { My hair becomes the fiber of cactus } \\
\text { roots }\end{array}$ \\
\hline $\begin{array}{l}\text { Ada mataku menjadi penyinar pagi } \\
\text { yang lembut }\end{array}$ & $\begin{array}{l}\text { My eyes become the soft lights of the } \\
\text { morning }\end{array}$ \\
\hline $\begin{array}{l}\text { Ada lidahku penyambung kasih } \\
\text { pertama }\end{array}$ & $\begin{array}{l}\text { My tongue is the connector of first } \\
\text { love }\end{array}$ \\
\hline Ada gigiku penggetap luka sehayat & My teeth are clenched in lifelong hurt \\
\hline $\begin{array}{l}\text { Ada leherku berputar pada debar } \\
\text { burung pucung }\end{array}$ & $\begin{array}{l}\text { My neck spins at the pulsation of the } \\
\text { heron }\end{array}$ \\
\hline $\begin{array}{l}\text { Ada halkumku bergerak disentuh } \\
\text { nama-Mu }\end{array}$ & $\begin{array}{l}\text { My larynx moved touched by Your } \\
\text { name }\end{array}$ \\
\hline $\begin{array}{l}\text { Ada rohku terupam bagai pualam di } \\
\text { piala-Mu }\end{array}$ & $\begin{array}{l}\text { My soul is burnished like marble on } \\
\text { Your trophy }\end{array}$ \\
\hline Ada Aku-Ku di dalam Aku-Mu. & There is I-Me in I-You] \\
\hline ( & \\
\hline
\end{tabular}

Only thinkers are able to give the mental effect required for perfecting oneself. Apart from thinkers, poets are also thinkers of art on the canvas of sounds in the melody of belles lettres flowing fluidly in the rivers of consciousness that are fine and pure, in the holy frame of fanatical sensitivity. The poem "Ziarah Rama-rama" (Landskap Ungu, 2010, p. 447) from the Ziarah Tanah Kudup collection is a fine poem which is as follows: 


\begin{tabular}{|c|c|}
\hline $\begin{array}{l}\text { Di keliling gedung sempurna } \\
\text { Hitam yang diukir sulam } \\
\text { Dan tegasan emas } \\
\text { Pusar gerak manusia } \\
\text { Mengecut ke pusat } \\
\text { Kadang mengembang } \\
\text { Seperti ubur-ubur mengelak batu } \\
\text { Arusnya berapung } \\
\text { Seperti pelampung putih } \\
\text { Yang oleng dalam sungai gelap } \\
\text { Maka sungai pun membaharui diri } \\
\text { (Aksara Usia, p. 20) }\end{array}$ & $\begin{array}{l}\text { [Around the perfect building } \\
\text { Blackened by alternated engraving } \\
\text { And golden beliefs } \\
\text { Whirls of human movements } \\
\text { Shrinking to the center } \\
\text { Sometimes expanding } \\
\text { Like jellyfish avoiding the rocks } \\
\text { The current floating } \\
\text { Like a white buoy } \\
\text { Swaying in a dark river } \\
\text { Thus the river self-revived] }\end{array}$ \\
\hline
\end{tabular}

The sound produced from the words in the poem succeeds in creating new metaphors other than those which already exist by enhancing the metaphorical form with imagination (Landskap Ungu, 2010, p. 144). He has critical insight in interpreting text, thus the writer regards the approach he uses to find the meaning of the message is in accordance with the hermeneutic claims.

\section{POETIC AESTHETICS}

Kemala places beautiful language, either the aesthetical or ethical aspect, as a communication system that involves symbols. The indirectness of expression in his poetry is due to the usage of metaphors that make up the main part of the language of poetry expression. When dealing with symbolic language, the definition can be best interpreted through hermeneutics as the interpretation methodology system developed by Paul Ricoeur. Poetry as a hermeneutic discourse is used as a philosophical perspective by using symbols as a starting point for exploring the possibility of meanings.

In his essay entitled "Malay-Islamic Poetic Aesthetics", the reader can detect the aesthetical concept Kemala uses in his research on poetry. The concept of beauty perceived by the writer is not only evaluated according to the artistic expression structure (based on the choice of words in expressing the quality of godliness and spirit or the light of God), but also the power felt from the words as the source, interpreted by mata 'aqal (the mind) or mata batin (the mind's eyes), which is the knowledge and power given to him (Landskap Ungu, 2010, p. 210). The interpretation made by these two sources are free to roam the world of the unseen until it penetrates the spirit of matter and goes directly to the secret of God, i.e. the secret of absolute 
truth. The ability of the poet to reach the secret of truth is what Kemala meant as the aesthetical element in Islamic poetry. Some ideas by Imam al-Ghazali who connected the relationship of the spirit with the symbols mishkat (niche), kaca (glass), lampu (lamp), pohon (tree) and minyak (oil) in Surah al-Nur, for example, are used as symbols that identify the spirit of the senses, the fanciful spirit and the spirit of the soul that merge with decisions of the mind. Kemala uses such symbolism to construct the position of the Malay Islamic poetry he studied, and it is found that this is where the aesthetics in poetry resides.

In Kemala's research, Malay Islamic poets whose poetry are studied according to the aesthetics which is evaluated on the existence of the merging of the real world and the unseen world soon succeeded in including the beauty of religious experience in the poetry bytes. The Malay Islamic poets include Amir Hamzah (in Nyanyi Sunyi), Nahmar Jamil (in Negeri Tercantik), Ali Ahmad (in Jalan ke Taman), Shafie Abu Bakar (in Puncak Rindu), Firdaus Abdullah (in Amira Sariyati ), Darma Mohamad (in Gernyut Nafas), Suhaimi Haji Muhammad (in Di Malam Gelita Ini), A. Aziz Deraman (in Kau dan Aku) and Kemala (in Pelabuhan Putih, Titir Zikir, Mim and 'Ayn). Kemala is a poet that has the capability to shift the spiritual power in a piece of work that explores the concept and understanding of God's light by entering into the religious experience in the form of self-experience. Suhaimi Haji Muhammad succeeded in shaping his ability to translate self-effect to whoever is found to be getting close and sitting next to God. However his spirit of mental light is still of openness, i.e. unlike Kemala who is more submerged in the unseen truth. Among Kemala's poetry he studied and is of interest regarding his ability to swim and submerge in God's spiritual light is the poem entitled Si Bisu in Titir Zikir (p. 228) as shown below:

\begin{tabular}{|l|l}
\hline Berikan si bisu & [Give the mute \\
p i s a $\mathrm{u}$ & $\mathrm{a} \mathrm{k} \mathrm{n}$ i f e \\
pisau kasih pisau jerih & knife of love knife of weariness \\
pisau bakal memisau & a knife for knifing \\
sedih & sorrow \\
berikan sedih & give sorrow \\
lidah & a tongue \\
lidah tasbih lidah fasih & a chanting tongue a fluent tongue \\
lidah bakal melidah & a tongue of speech] \\
\end{tabular}


The aesthetical power in the poetry above is in the form of dynamic perception with its pure art definition. The element of repetition of words and the apt choice of words in the phrases are only a technical issue of low aesthetical quality if compared with the power of the leap in spiritual experience inspired from the base of the mental domain. It is from this domain the light of God radiates from the unseen world of the spiritual realm of the mind.

\section{IMAGINATION AS EVIDENCE OF POETIC ART}

In the research on Latiff Mohidin's poetry, Kemala acknowledges that "imagination" can be used as evidence of poetic art, i.e. the fine beauty that not only focuses the viewpoint but also inverts it. Latiff often uses irony as a tool to breathe freshness into the mind by spiritual symbolism, as expressed in "Gerimis Tumbuh" (in Pesisir Waktu) below:

\begin{tabular}{|l|l|}
\hline 1 & {$[1$} \\
esok hari & tomorrow \\
bunga-bunga hujan & the seeds of rain \\
akan membiak di sana & will propagate there \\
akarnya melata melengkar & their roots cascading and coiling \\
ke pintu ke ruang jendela & to the door to the window space \\
menggelapkan pandangan & obscuring the view $]$ \\
\hline
\end{tabular}

In the poem above, the law of nature solves human problems in accordance with what has been preordained by God. To Kemala, the poem presents the poet's awareness of every element and all that is created in the world to carry out their individual tasks (to obey God's Command) apart from a religious consciousness through the surrealistic approach (Landskap Ungu, 2010, p. 101).

According to Kemala, loneliness is evident in Latiff's poetry. As in the stillness that slowly seeps in, Latiff provides us with the meanings of pasir (sand), kerikil (gravel), kabus (mist) and angin (wind) as the symbols of God's greatness in his ability to adorn the lines of his poetry with the light of stillness, fresh, yet drenched in the awe and peculiarity of the situation of nature: 
Aku duduk di lantai rumah malam Mengingatkan kehebatan perintah-Mu

burung-burung yang terbang tertidur daun-daun gugur bagai serpihan batu.

Siapakah akan lahir di saat begini?

Kiambang laut membiak di puncak rimba gunung-gunung tumbuh di bawah kulit bumi

keheningan menghirup abadi di langit$\mathrm{Mu}$.

(Pesisir Waktu, p. 4)
[I sit on the house floor the night reminiscing the magnitude of Your command

birds that fly fall asleep

leaves are falling like fragments of gravel

Who will be born in moments like this?

Sea duckweed flourishes above the jungle

mountains grow below the earth surface

stillness sips eternally in Your sky]

In the study on Zaihasra's poetry, Kemala discerns the imagination of protests uttered subtly in the expression about herself. Self-experience transforms into an element of imagination for the reader of Zaihasra's poetry. Self-experience can be conveyed to the reader in the context of understanding the consciousness of suffering expressed by the poet. The quality of Zaihasra's poetic art is accompanied by a dual feeling: the journey of fate and disappointment, as expressed in the following verse in quatrains, (Landskap Ungu 2010, p. 43):

\begin{tabular}{|l|l|}
\hline Waktu kau berangkat tua, minum dua & [As time you grow older, drinking \\
kali bagian anggurmu & twice your portion of grapes \\
Walau piala di tanganmu tergetar, & Even if the chalice in your hand \\
minum & quivers, drink \\
Waktu begini lama bercumbu denganmu. & Moments like this have seduced you \\
Kini tertawalah pada si badut, tertawa & for long \\
dan minum & Now laugh at the clown, laugh and \\
& drink] \\
\hline
\end{tabular}

The beauty of this poem does not only lie in the structure of the phrases, but also in the hidden content of the words. In the $80 \mathrm{~s}$, Zaihasra showed changes in her style of expression or diction structure in her poems. It may be the reason why Kemala forwarded his opinion in his research on Zaihasra's poems. The last phrase "Kini tertawalah pada si badut, tertawa and minum" ("Now laugh at the clown, laugh and drink") is among the poetic structures that indicate changes in the structural aspect that succeeded in explaining the hidden contents artistically. 
Zaihasra's imagination does not divert too far from the meaning of the words in her poetry. The spirit of her fancy is still fresh in the phrases. This ability is expressed in part of the poem "Kupilih Jalan Ini" taken from the Laut, Pohon and Kota collection as shown below (Landskap Ungu 2010, p. 94):

\begin{tabular}{|l|l|}
\hline Kupilih perjalanan ini & {$[$ I choose this path } \\
Mencipta keindahan & Creating beauty \\
Membuang kehitaman & Discarding darkness \\
Melalunya aku kembali ke rumah & Going through it I return to my original \\
asal & home \\
Yang selamanya menunggu diriku & That will always be there for me \\
Membawa kembang sejuta harum & Bringing the blossoms of million scents] \\
\hline
\end{tabular}

Imagination as the producer of visual image is accomplished through analogical language or transient language. According to Coleridge who is said to have made a significant contribution to the theory of criticism, imagination is a magical power that accompanies phrases. In Zaihasra's poetry, this power exposes the truth, showing balance, highlighting the quality of being new and refreshing for her time. Imagination too is a gift, in the belief that knowledge and the principle of reality can be mastered by examining thoughts such as those expressed in Zaihasra's poem above, as well as the poems "Riverside Park", "Musim Rontok" by Anwar Ridhwan (in Puisi Baharu Melayu 19611986, 1990) (Landskap Ungu, 2010, pp. 166-167) as follows:

\begin{tabular}{|l|l|}
\hline Pohon rontok meluruhkan kepingan & [Shedding trees discarding pieces of \\
tembaga & copper \\
Senyap-senyap mengajak dingin merata & Silently inviting the spreading coolness \\
Antara ranting dan lengan tembok & Between the twigs and the arm of the \\
tua & old wall \\
Meredupi lereng taman melihat senja & Shading the garden sides to witness the \\
Aku senang sekali dudukatau berbaring & twilight \\
Bermandi dingin yang turun dari & I am happy sitting or lying down \\
ranting bening & Covered with coolness from the limpid \\
Antara kelepak merpati dan lincah & branches \\
bajing. & Among the flapping pigeons and agile \\
Ada orang berlari berebut sisa panas & squirrels \\
Sepanjang lorong pohon-pohon & Someone running, snatching heat \\
menurus & remains \\
Ketika ada pasangan tua duduk di & Along the lane trees stand erect \\
bangku & As an elderly couple sits on the bench \\
Aku bersiap dengan kameraku & I am ready with my camera \\
Kunantikan saat sepasang merpati & Waiting for the moment a pair of \\
Terbang perlahan atas dua sejoli & pigeons \\
Klik! & Fly slowly above the two love-birds \\
& Click!] \\
\hline
\end{tabular}


The imagination in the above poetry is realized in the form of thoughts and feelings of the poet on his creative work. A new consciousness is raised by the poet through the analogy of experience in a foreign country to render wisdom to normal thinking making it come alive by the perception of artistic quality in the mental pattern of his message. Thus, based on this imagination, Kemala selected this poem as his material for analysis of the contribution of Selangor poets in the new dynamics of discovery of meaning in the national Malay poetic world.

Although Kemala is not aware of the method he used to study Islamic poetry, he must have perceived imagination as the poetic art device in the process of choosing poetry with quality as samples for analysis. The power of imagination in this nature poetry above is not that deep, since its cliches are rather weak to be able to relate it to identity struggle or cultural supremacy or the question of justice, humanity and world peace. Only its beauty succeeds in pulling together the aspects of ideas which are embedded in the beauty of nature as God's perfect creation on earth.

\section{KEMALA'S THOUGHTS AND POETICAL INSIGHT}

Kemala is not always categorized as a sufi poet but a philosopher. He has written many poems (sajak) in several poetry collections such as Pelabuhan Putih, Kaktuskaktus, Titir Zikir and Ziarah Tanah Kudup which focus on his interest in the issue of the struggle of the cultural identity of the pure Malay, including the struggle against local and universal injustice, humanitarianism and the fate of the Malay generation in their own country. The content of his poems focus cognitive interest in the messages that are presented in his own way. He scaled the foundations of cultural existence in a construction which places identity and authority in the right places in terms of the requirements of the Islamic religion. Kemala expands the idea of morality in his poems in the effort to enlighten according to circumstances, standing by his original argument by alienating the process of self-development as something crucial according to the theory of knowledge. His views on the status of the poetry of other poets do not point towards self-development of the human species but focus on human characteristics, having being provided with minds and feelings.

The process he demands from the system of action and experience is distinguished from the reconstruction that is required to understand his poetry, and the poetry he studies. For the poetry of other poets, since lacking in philosophical characteristics, reconstruction does not play a role 
in interpretation. This is because the poems of others are less varied. In his pursuit to explain rational reconstruction as pure knowledge bound by the system of experience, Kemala refined his appreciation towards some of the features of poetic discourse of other poets as the complement to the perfection of authorship or versification in the history of poetry development in Malaysia.

Ideas regarding "blank identity" from the unity of ego (as mentioned by Kant) often point the poets' social criticism towards the long established experience system which requires immediate remedies because the current social situation seems to be in such a critical state to be able to continue vibrantly as in the era before Malaya's independence from the sovereignty of English colonialism, which generated sources of sorrow for the generation that followed or the future generations. This is found to be true as seen in many poetry that is not Islamic poetry -- a kind of interest that focuses on other types of social criticism.

Kemala perceives the contents of poetry as the spirit that no longer knows and takes care of the self that does not fade with philosophy in its absolute truth. Kemala acknowledges the concept of poetry as a reflection that motivates poets as thinkers by confining philosophy to the logic of beneficial knowledge. A view that coincides with Habermas ideas, Kemala's opinion seems to agree that philosophy should be free from the power that faces something absolute. Philosophers must refrain themselves from thinking of absolute matters, then only the content or message of the poetry can be interpreted comprehensively even beyond the language barrier. The reason for self-restraint is to respect the thinking to be as authentic as it was created i.e. by not betraying it based on the evaluation of empirical truth. With this belief, moral concerns and struggle can be upheld since the definition that perceives spiritual truth cannot be sustained in its positive quality based on religious evaluation, especially with regards to Islamic faith.

A specific category of human maneuvering in poetry is part of the findings of society which is historical in nature and can always vary. On the possible variability of this finding, thus Kemala is calling all Muslims to start the endeavor of returning to a new, peaceful and brighter world. This can be seen from the definition of paradigm shift of the new society so that it will change from the old paradigm that is deteriorating. We can relate the religious spiritual aspect to this idea. 


\section{CONCLUSION}

In Landskap Ungu, Kemala is at once a thinker as well as an interpreter, serious researcher and creator of poetic art. Kemala's view is that language and tradition cannot be separated from each other. Tradition is a media that transforms and develops language. He did an interpretive compatibility on tradition participated in by the new generation. His interpretive compatibility plays a significant role in the development of tradition. True interpreters usually come from the same group as the poet whose subject is being studied and analyzed, so that the interpreters' mould for comparison to understand the tradition for choosing is based on that particular foundation. Kemala is a fine example of having this art. This is because he focuses on the features of the contents of other poets' poetry from the traditional perspective and its perpetuity, especially those relating to religious belief.

The focus on the layers of definition is continuously explored by him in his effort to ensure that there are no loop-holes that can harm the perpetuation. What is proven from his studies on the poetic materials in his effort to scrutinize the interesting development of Malay poetry. Kemala often broaches new aspects and also views whether the old elements should be changed or retained in order to give a basic philological experience related to the meaning of texts. His contribution is exceptional and has proven to be significant in the development of Malay poetry.

\section{REFERENCE}

Aceh, Abubakar. (1989). Pengantar sejarah sufi dan tasawuf. Solo: Ramadhani. Ahmad Kamal Abdullah \& Ahmad Razali Haji Yusof. (1990). Puisi baharu Melayu, 1961-1986. Kuala Lumpur: Dewan Bahasa dan Pustaka.

Ahmad Kamal Abdullah. (2010). Landskap Ungu. Essay collection. Serdang: Universiti Putra Malaysia Publication.

Bisri, A. Mustofa (2000). Sajak-sajak cinta Gandrung. Rembang: Al-Ibris.

Hadi W.M., Abdul. (2001). Tasawuf yang tertindas. Jakarta: Paramadina.

Hamka. (1984). Tasawuf: perkembangan dan pemurniannya. Jakarta: Pustaka Panjimas.

Kemala. (1976). Kaktus-kaktus. Kuala Lumpur: Fargoes Press.

Kemala. (1983). 'Ayn.Poetry collections. Kuala Lumpur: Dewan Bahasa dan Pustaka. Kemala. (1989). Pelabuhan Putih. Poetry collection. Kuala Lumpur: Dewan Bahasa dan Pustaka

Kemala (ed.). (1989). Gejala: Esei dan Kritikan Puisi Melayu Moden 1955-1986. Kuala Lumpur: Dewan Bahasa dan Pustaka.

Kemala. (1999). Mim. Poetry collection. Kuala Lumpur. Dewan Bahasa Dan Pustaka. 
MALAY LITERATURE VOLUME 30 NUMBER 1 JUNE 2017

Kemala. (2006). Ziarah Tanah Kudup. Poetry collection. Kuala Lumpur: Dewan Bahasa Dan Pustaka.

Kemala. (1995). Titir Zikir. Poetry collection. Kuala Lumpur: Dewan Bahasa Dan Pustaka.

Latiff, A. Mohidin. (1981). Pesisir waktu. Poetry collection. Kuala Lumpur: Dewan Bahasa Dan Pustaka.

McCarthy, Thomas. (2009).Teori Kritis Jürgen Habermas. Bantul: Kreasi Wacana, Indonesia.

Md. Salleh, Pangeran. (1965). Syair rakis. Bandar Seri Begawan: Dewan Bahasa Dan Pustaka.

Nasution, Harun. (1990). Filsafat dan mistisisme dalam Islam. Akarta: Bulan Bintang. Zaihasra. (1988). Laut, pohon dan kota. Poetry collections. Kuala Lumpur: Dewan Bahasa dan Pustaka. 